\title{
Recombinant Eotaxin
}

National Cancer Institute

\section{Source}

National Cancer Institute. Recombinant Eotaxin. NCI Thesaurus. Code C1531.

A recombinant therapeutic agent which is chemically identical to or similar to the endogenous chemokine eotaxin, a member of the C-C cytokine family which is chemotactic for eosinophils. The early increase in eotaxin paralleled eosinophil infiltration in the asthmatic lung tissue in animal models hinted a potential role for eotaxin in immunotherapy. 